\title{
EKSISTENSI BAHASA INDONESIA DI TENGAH BAHASA KARO DI DESA TIGA PANAH KABUPATEN KARO
}

\author{
Frida Dian Handini \\ Universitas Quality Berastagi, Indonesia \\ fridadianhandinilubis@gmail.com
}

\begin{abstract}
Abstrak
Penelitian ini merupakan penelitian deskriptif kualitatif. Subjek penelitian ini yaitu seorang penduduk berinisial LAH yang tinggal di Tanah Karo. Penelitian ini berfokus pada eksistensi bahasa. Tujuan dari penelitian ini adalah untuk mengetahui bahasa apa yang digunakan oleh orang tua dan lingkungan anak tersebut, kemudian peneliti juga meneliti bagaimana cara LAH mempertahankan bahasa Indonesia sebagai bahasa pertamanya. Dalam proses pengumpulan data, peneliti melakukan observasi ke lapangan dan mewawancara LAH serta keluarga dan lingkungan tempat tinggal subjek penelitian. Peneliti merekam percakapan sebagai bukti bahwa LAH bahkan tidak memiliki logat Karo dan juga menunjukkan apakah ada perbedaan logat antara subjek, orang tua subjek, dan juga penduduk lingkungan sekitarnya. Selain itu peneliti juga memberikan angket pada LAH dan keluarganya untuk mengetahui faktor apa saja yang menyebabkan pemertahanan Bahasa Indonesia oleh subjek penelitian. Data dalam penelitian ini dianalisis menggunakan interaktif model. Berdasarkan hasil analisis data, peneliti menemukan faktor-faktor pemertahanan Bahasa Indonesia oleh subjek penelitian yaitu faktor agama, pendidikan, identitas, sikap bahasa, campur kode, dan jumlah penutur. Penelitian ini diharapkan dapat memberikan manfaat secara teoritis dan praktis. Selain itu, penelitian ini diharapkan dapat menjadi tambahan referensi bagi peneliti selanjutnya yang tertarik dengan bidang sosiolinguistik khususnya di bidang pemertahanan bahasa.
\end{abstract}

Kata kunci: pemertahanan bahasa, bahasa Indonesia, bahasa Karo

\begin{abstract}
This research is a qualitative descriptive study. The subject of this research is a resident with the initials LAH who lives in Tanah Karo. This study focuses on the existence of language. The purpose of this study was to determine what language the parents and child's environment were using. Then the researcher also examined how LAH maintained Indonesian as her first language. In the process of data collection, researchers conducted field observations and interviewed LAH and the family and environment where the research subjects lived. The researcher recorded the conversation as evidence that LAH did not even have a Karo accent and also showed whether there was a difference in accent between the subject, the subject's parents, and also the residents of the surrounding environment. In addition, the researcher also gave a questionnaire to LAH and her family to find out what factors led to the retention of Indonesian by the research subjects. The data in this study were analyzed using an interactive model. Based on the results of data analysis, the researcher found the factors of maintaining Indonesian by the research subjects, namely factors of religion, education, identity, language attitudes, code mixing, and the number of speakers. This research is expected to provide theoretical and practical benefits. In addition, this research is expected to be an additional reference for future researchers who are interested in the sociolinguistics field, especially in the field of language maintenance.
\end{abstract}

Keywords: language retention, Indonesian, Karo language. 


\section{PENDAHULUAN}

Bahasa masih memegang peranan penting dalam kehidupan bersosial. Dengan menggunakan bahasa, masyarakat berinteraksi baik secara lisan maupun tulisan. Wibowo berpendapat bahasa adalah sistem simbol bunyi yang bermakna dan berartikulasi (dihasilkan oleh alat ucap) yang bersifat arbitrer dan konvensional, yang dipakai sebagai alat berkomunikasi oleh sekelompok manusia untuk melahirkan perasaan dan pikiran. Bahasa adalah sebuah sistem, artinya, bahasa dibentuk oleh sejumlah komponen yang berpola secara tetap dan dapat dikaidahkan ${ }^{1}$. Sistem bahasa berupa lambang-lambang bunyi, setiap lambang bahasa melambangkan sesuatu yang disebut makna atau konsep. Karena setiap lambang bunyi itu memiliki atau menyatakan suatu konsep atau makna, maka dapat disimpulkan bahwa setiap suatu ujaran bahasa memiliki makna. ${ }^{2}$ Seperti di Indonesia, setiap daerah memiliki sistem kebahasaannya masing-masing. Contohnya seperti di wilayah kabupaten Karo, masyakarakat di daerah tersebut memiliki bahasa daerah tersendiri.

Suku Karo adalah suku yang mendiami dataran tinggi Karo Provinsi Sumatera Utara, Indonesia. Suku ini merupakan salah satu suku terbesar dalam Sumatera Utara. Nama suku ini dijadikan salah satu nama kabupaten di salah satu wilayah yang mereka diami (dataran tinggi Karo) yaitu Tanah Karo. Suku ini memiliki bahasa sendiri yang disebut Bahasa Karo atau Cakap Karo. Sebagai penduduk yang tinggal di daerah yang masih aktif dalam penggunaan bahasa daerah, seharusnya bahasa daerah tersebut menjadi bahasa pertama atau bahasa Ibu. Dengan kata lain, bahasa Karo masih aktif digunakan di daerah ini. Penduduk tanah Karo memiliki bahasa tersendiri (bahasa Karo) beserta logat khasnya. Namun peneliti menemukan satu fakta yang menarik di lapangan yaitu ada seorang penduduk tanah Karo yang lahir dan besar di Karo namun dia tidak aktif dan bahkan tidak memiliki logat Karo saat berbicara. Saat peneliti mewawancara anak tersebut, dia mengaku bahwa bahasa pertamanya adalah bahasa Indonesia, bukan bahasa Karo. Itu disebabkan karena dia bukan suku Karo melainkan Sunda.

Berdasarkan fakta tersebut peneliti tertarik untuk meneliti mengenai bahasa Indonesia yang dipertahankan anak tersebut di tengah bahasa Karo. Peneliti akan mewawancara lebih lanjut anak tersebut mengenai bahasa apa yang digunakan kedua orang tua dan lingkungan anak tersebut selain itu peneliti juga ingin mengetahui mengapa dia mempertahankan bahasa Indonesia padahal dia tinggal di tanah Karo yang notabene memiliki bahasa daerah sendiri.

\footnotetext{
${ }^{1}$ Wahyu Wibowo, Otonomi Bahasa 7 Strategi Tulis Pragmatik bagi Praktisi Bisnis dan Mahasiswa, (Jakarta: Gramedia Pustaka Utama, 2001), 24

${ }^{2}$ Abdul Chaer dan Leonie Agustina, Sosiolinguistik. (Jakarta: Rineka Cipta, 2004), 5
} 
Lalu peneliti juga akan meneliti bagaimana cara anak tersebut dalam mempertahankan bahasa pertamanya.

\section{KAJIAN TEORI}

Bahasa merupakan alat komunikasi utama manusia dalam membangun interaksi. Melalui bahasa manusia mengungkapkan dan berkomunikasi secara dua arah. Dalam suatu daerah bahasa bisa terdiri dari beberapa macam bahasa maupun logat yang berbeda. Seperti di Sumatera Utara, khususnya di kabupaten Karo, terdapat satu bahasa daerah yang digunakan di kawasan ini, yaitu bahasa Karo. Widianto berpendapat bahwa paradigma masyarakat abad 21 menilai bahwa bahasa asing memiliki prestise lebih tinggi dibandingkan bahasa nasional dan bahasa daerah. ${ }^{3}$ Dengan kata lain, bahasa daerah berada di prioritas ketiga dalam penggunaannya setelah bahasa nasional dan bahasa asing. Masyarakat lebih memilih menggunakan bahasa nasional dan bahasa asing dalam berkomunikasi. Penutur bahasa asing juga dinilai lebih berpendidikan dan memiliki strata sosial lebih tinggi. Begitu pula sebaliknya, penutur bahasa daerah dinilai memiliki strata sosial di bawah penutur bahasa nasional dan bahasa asing.

Pemertahanan dan pergeseran bahasa muncul seperti dua mata sisi mata uang. Kedua hal ini terjadi akibat terjadinya fenomena kebahasaan yang merupakan hasil dari pemilihan bahasa (language choice). Pilihan bahasa diartikan sebagai hasil dari proses memilih suatu bahasa yang dilakukan oleh masyarakat bahasa atau penutur multibahasawan. Artinya, penutur tersebut menguasai dua bahasa atau lebih sehingga dapat memilih bahasa yang digunakan dalam tindak tutur melalui variasi tunggal bahasa, alih kode, dan campur kode. ${ }^{4}$ Pemertahanan bahasa dapat dilakukan oleh penutur multibahasa. Multibahasa dapat menggunakan pemilihan bahasa dalam melakukan pemertahanan bahasa.

Subjek penelitian ini merupakan keturunan Sunda yang tinggal di kabupaten Karo dan menggunakan bahasa Indonesia sebagai bahasa sehari-hari. LAH menuturkan bahwa kedua orang tuanya yang merupakan suku Sunda jarang menggunakan bahasa Sunda dalam berkomunikasi di rumah. Bila satu kelompok baru datang ke tempat lain dan bercampur dengan kelompok setempat, maka akan terjadilah pergeseran bahasa (language shift). Kelompok pendatang ini akan melupakan sebagian bahasanya dan 'terpaksa' memperoleh bahasa setempat. Alasannya karena kelompok pendatang ini harus menyesuaikan diri dengan

\footnotetext{
3 Eko Widianto. "Pilihan Bahasa dalam Interaksi Pembelajaran Bahasa Indonesia bagi Penutur Asing". Seloka: Jurnal Pendidikan Bahasa dan Sastra Indonesia. Volume 5 nomor 2 tahun 2016, 124-135. ${ }^{4}$ ibid
} 
situasi baru tempat mereka berada. Selanjutnya kelompok pendatang ini akan mempergunakan dua bahasa, yaitu bahasa nasional dan bahasa daerah setempat. ${ }^{5}$ Grimes menyebutkan sebab utama kepunahan bahasa ada di keluarga. ${ }^{6}$ Saat keluarga tidak lagi mengajarkan bahasa ibu kepada anak-anaknya dan tidak lagi secara aktif menggunakannya di rumah dan dalam berbagai ranah komunikasi.

Dalam interaksi sosial terjadi saling pengaruh. Orang yang lebih aktif akan mendominasi interaksi itu. ${ }^{7}$ Sebaliknya, pada penelitian ini ditemukan fakta yang berbeda. Bahasa yang dominan digunakan di kabupaten Karo adalah bahasa Karo, yang artinya penuturnya lebih banyak dan aktif dan seharusnya bahasa ini menjadi bahasa ibu bagi orang yang tinggal dan besar di lingkungan tanah Karo, namun subjek penelitian ini tidak terpengaruh dengan lingkungannya dan menggunakan bahasa Indonesia lengkap dengan logat yang sangat baik.

Pemertahanan pemertahanan bahasa suatu komunitas secara kolektif menentukan untuk melanjutkan memakai bahasa yang sudah biasa dipakai. ${ }^{8}$ Menurut Sumarsono dalam laporan penelitiannya mengenai pemertahanan penggunaan bahasa Melayu Loloan di desa Loloan yang termasuk dalam wilayah kota Nagara, Bali, ada beberapa faktor yang menyebabkan bahasa itu dapat bertahan, yaitu: pertama, wilayah pemukiman mereka terkonsentrasi pada satu tempat yang secara geografis agak terpisah dari wilayah pemukiman masyarakat Bali. Kedua, adanya toleransi dari masyarakat mayoritas Bali yang mau menggunakan bahasa Melayu Loloan dalam berinteraksi dengan golongan minoritas Loloan, meskipun dalam interaksi itu kadang-kadang digunakan juga bahasa Bali. Ketiga, anggota masyarakat Loloan, mempunyai sikap keislaman yang tidak akomodatif terhadap masyarakat, budaya, dan bahasa Bali. Pandangan seperti ini dan ditambah dengan terkonsentrasinya masyarakat Loloan ini menyebabkan minimnya interaksi fisik antara masyarakat Loloan yang minoritas dan masyarakat Bali yang mayoritas. Akibatnya pula menjadi tidak digunakannya bahasa Bali dalam interaksi intrakelompok dalam masyarakat Loloan. Keempat, adanya loyalitas yang tinggi dari anggota masyarakat Loloan terhadap bahasa Melayu Loloan sebagai konsekuensi kedudukan atau status bahasa ini yang menjadi lambang identitas diri masyarakat Loloan yang beragama Islam; sedangkan bahasa Bali dianggap sebagai lambang

\footnotetext{
${ }^{5}$ Nurdin Bramono \& Mifta Rahman, Pergeseran dan Pemertahanan Bahasa.Diglossia : Jurnal Kajian Ilmiah Kebahasaan dan Kesusasstraaan, vol 4 no 1 tahun 2012, 256

${ }^{6}$ Maria Botifar. Pemertahanan Bahasa dan Pengembangan Kurikulum Bahasa Berbasis Analisis Kebutuhan, Prosiding Seminar Nasional Bulan Bahasa UNIB 2015, 207

${ }^{7}$ Nurdin Bramono \& Mifta Rahman, ibid

${ }^{8} \mathrm{Ibid}$
} 
identitas dari masyarakat Bali yang beragama Hindu. Oleh karena itu, penggunaan bahasa Bali ditolak untuk kegiatan-kegiatan intrakelompok, terutama dalam ranah agama. Kelima, adanya kesinambungan pengalihan bahasa Melayu Loloan dari generasi terdahulu ke generasi berikutnya.

Menurut Sumarsono, ada beberapa faktor yang menyebabkan pemertahanan bahasa, yaitu ekonomi, agama, dan politik. ${ }^{9}$ Pendapat lain menjelaskan bahwa faktor-faktor yang menyebabkan pemertahanan bahasa adalah jumlah penutur, tempat tinggal, identitas dan kebanggaan budaya serta kondisi ekonomi yang baik. ${ }^{10}$ Sementara itu, Romaine berpendapat bahwa faktor-faktor yang mempengaruhi pemertahanan bahasa diantaranya migrasi, ranah, partisipan, ekonomi, budaya, politik, agama, latar belakang pendidikan, menghubungi famili di kampung halaman, sikap bahasa, perkawinan tidak sesuku, administrasi, konsentrai tempat tinggal, pekerjaan, umur, jenis kelamin, campur kode, dan alih kode. ${ }^{11}$ Fishman menyatakan bahwa yang mempengaruhi bahasa dan pemakaiannya bukan hanya berdasarkan faktor linguistik, tetapi faktor non-linguistik juga turut andil, seperti faktor sosial dan situasional. ${ }^{12}$ Faktor sosial yang mempengaruhi diantaranya status sosial, tingkat pendidikan, umur, dan jenis kelamin. Sementara untuk faktor situasional meliputi siapa yang berbicara, dengan apa, kepada siapa, dimana, dan masalah apa. Berdasarkan beberapa pendapat diatas, dapat disimpulkan bahwa pemertahanan bahasa terjadi karena beberapa faktor, yaitu:

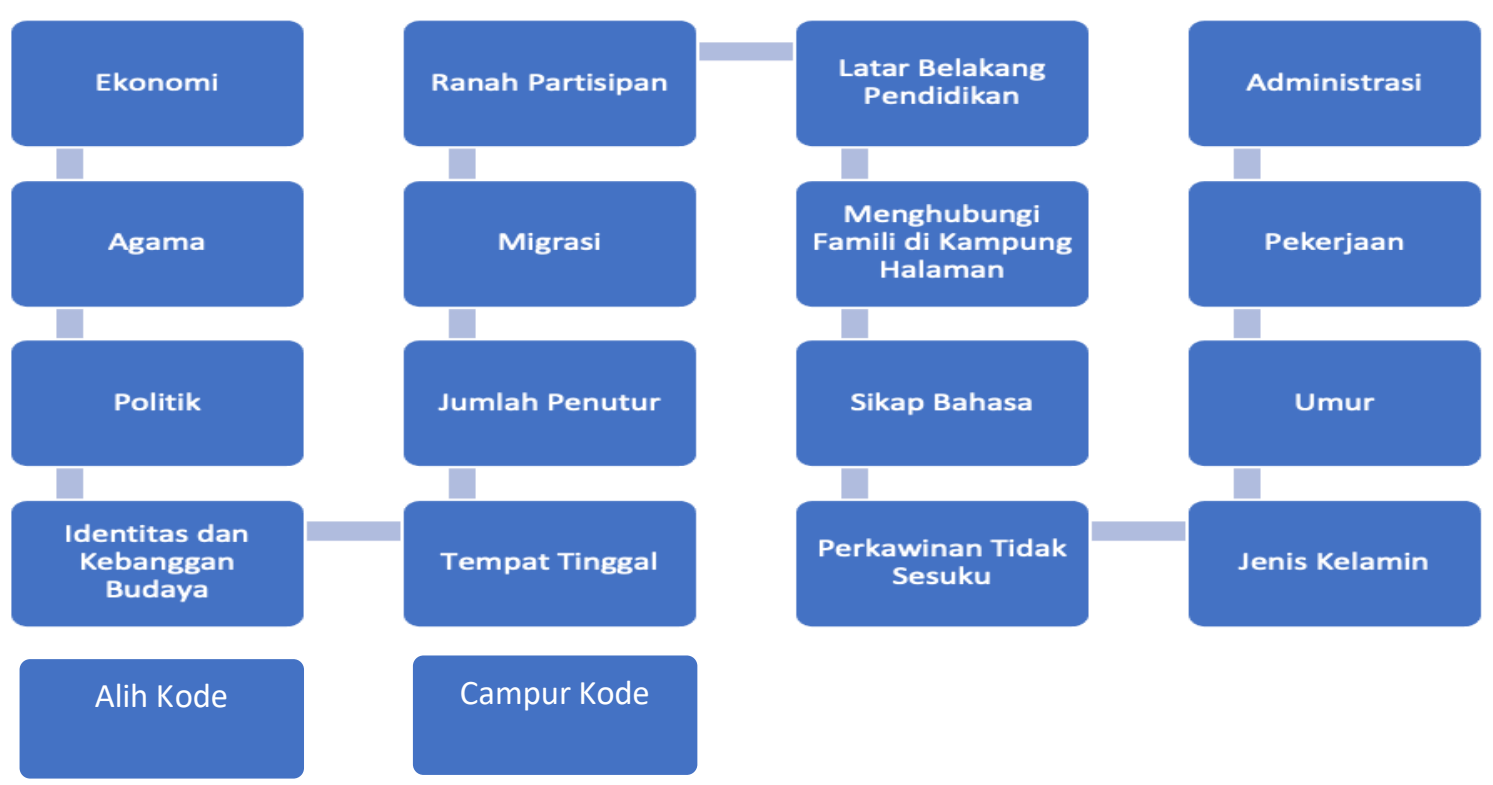

\footnotetext{
${ }^{9}$ Sumarsono. Sosiolinguistik. (Yogyakarta: Sabda, 2004), 34

${ }^{10}$ Iwan Indrawan Jendra, Sociolinguistics: The Study of Societies' Language. Yogyakarta: Graha IImu, 2010), 54

${ }^{11}$ Romaine. Language in Society: An Introduction to Sociolinguistics. New York: Oxford University Press, 2000), 32

${ }^{12}$ Aslinda dan Leni Syafyahya. Pengantar Sosiolinguistik. Bandung: Refika Aditama, 2010), 26
} 


\section{Gambar 1.}

Faktor Pemertahanan Bahasa Menurut Para Ahli

Pada penelitian ini, subjek penelitian ini menggunakan bahasa nasional, bahasa Indonesia, sebagai bahasanya untuk berkomunikasi sehari-hari. Sedangkan subjek bertempat tinggal di kabupaten Karo yang notabene memiliki bahasa daerahnya sendiri. Berdasarkan temuan ini, peneliti tertarik untuk melihat bahasa apa yang digunakan oleh orang tua dan lingkungan anak tersebut lalu peneliti juga meneliti bagaimana cara LAH mempertahankan bahasa Indonesia sebagai bahasa pertamanya.

\section{METODE PENELITIAN}

Penelitian ini menggunakan metode deskriptif kualitatif dikarenakan peneliti ingin mengetahui dan mendeskripsikan fenomena yang berhubungan dengan pemertahanan bahasa Indonesia ditengah bahasa Karo sebagai bahasa daerah. Metode deskriptif dirancang bagi peneliti untuk mengumpulkan informasi sesuai dengan kondisi saat ini. Penelitian desktiptif mendeskripsikan dan menginterpretasi apa yang sedang terjadi. Dengan kata lain, penelitian deskriptif kualitatif digunakan untuk mendeskripsikan fenomena yang sedang terjadi di lapangan. Informan yang menjadi subjek dari penelitian ini adalah Leony Aisyah Habibah (LAH), seorang yang tinggal di desa Tiga Panah kabupaten Karo dan objeknya adalah ujaran yang dikeluarkan oleh subjek tersebut. Instrumen yang digunakan dalam penelitian ini adalah lembar observasi, tape recorder, dan kamera untuk mengumpulkan data dan sebagai bahan dokumentasi penelitian.

Peneliti mengumpulkan data dengan cara melakukan observasi, wawancara dan menyerahkan angket untuk diisi oleh subjek penelitian dan juga orang-orang yang tinggal dan berinteraksi dengan subjek. Dalam mengumpulkan data, peneliti melakukan observasi ke lapangan dan mewawancara subjek penelitian. Hasil lembar observasi dan hasil rekaman suara maupun video dianalisis untuk mengetahui bahasa apa yang digunakan oleh orang tua dan lingkungan anak tersebut dan bagaimana cara LAH mempertahankan bahasa Indonesia sebagai bahasa pertamanya.

Peneliti menggunakan teknik analisis data Interaktif Model oleh Miles, Huberman, \& Saldana ${ }^{13}$, dimana terdiri dari 4 tahap, yaitu a. pengumpulan data (data collection), b. pemadatan/penyingkatan data (data condensation), c. pemaparan data (data display), dan d. menyimpulkan data (conclusion drawing/verifying). Dalam proses pemadatan data (data

${ }^{13}$ Miles, Huberman, Saldana. Qualitative Data Analysis: A Methods Sourcebook. (USA: Sage, 2014), 51 
condensation) terdapat beberapa langkah yaitu menyeleksi, memfokuskan, menyederhanakan, meringkas, dan mengubah data ke dalam tabel/garifk, atau sejenisnya. Untuk lebih jelasnya dapat dilihat pada gambar 1.2 dibawah.

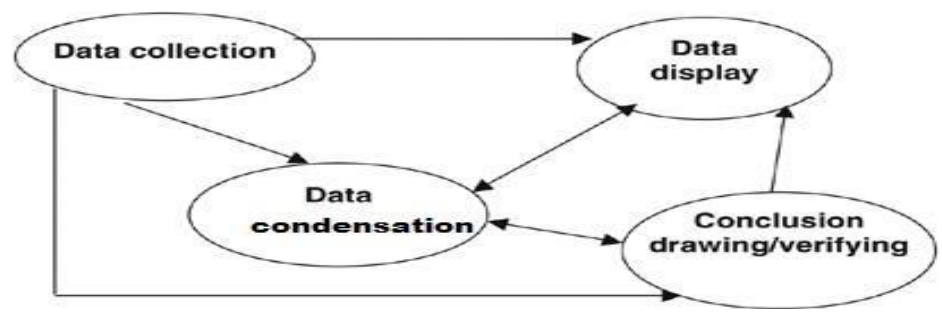

Gambar 2.

Interaktif Model

Untuk lebih jelasnya, interaktif model dapat dijabarkan sebagai berikut:

1. Pengumpulan data (Data collection). Peneliti mengumpulkan data; ujaran yang diujarkan oleh subjek penelitian dengan menggunakan tape recorder dan video recorder.

2. Pemadatan/penyingkatan data (Data condensation). Setelah peneliti mendapatkan ujaran dari subjek penelitian, peneliti mulai memadatkan/menyingkatkan data yang sudah didapat. Ujaran dibedakan menjadi ujaran bahasa Indonesia dan ujaran bahasa Karo maupun campurannya.

3. Penyajian Data (Data display). Setelah data dipersingkat atau dipadatkan, peneliti mulai menyajikan data yang ada untuk kemudian ditarik kesimpulan dari hasil penelitian yang sudah dilakukan.

4. Kesimpulan (Conclusion). Pada tahap akhir, peneliti menarik kesimpulan berdasarkan analisis data yang sudah dilakukan selama penelitian.

\section{HASIL \& PEMBAHASAN}

Penelitian ini adalah penelitian kualitatif yang mendeskripsikan suatu keadaan pemertahanan bahasa Indonesia oleh subjek, LAH yang berdomisili di desa Tiga Panah kabupaten Karo. Penelitian ini dimulai dengan peneliti mengunjungi desa tempat tinggal subjek penelitian, lalu dilanjutkan dengan observasi, wawancara, dan juga pengisian angket oleh subjek penelitian maupun orang-orang yang berada di lingkungan subjek. Ini dilakukan untuk melihat apa saja faktor yang menyebabkan subjek mempetahankan penggunaan bahasa Indonesia di daerah kabupaten Karo yang notabene memiliki bahasa daerahnya tersendiri, yaitu bahasa Karo. 
Setelah dilakukan beberapa kali kunjungan untuk observasi dan wawancara, peneliti menemukan bahwa subjek penelitian ini merupakan suku Sunda yang lahir dan besar di kabupaten Karo. Dalam komunikasi sehari-hari, orang tua subjek menggunakan bahasa Indonesia pada anak-anaknya, termasuk LAH sebagai subjek penelitian ini. Ini dikarenakan oleh faktor suku dan juga lingkungan mereka tinggal. Ditemukan bahwa penduduk tempat mereka tinggal juga menggunakan bahasa Indonesia, terutama anak-anak di lingkungan tersebut. Bedanya hanya anak-anak lingkungan tersebut menggunakan bahasa Indonesia dengan logat Karo, sementara LAH menggunakan bahasa Indonesia tanpa logat Karo. Menurut hasil observasi, wawancara, beserta angket yang telah diberikan pada subjek penelitian, didapatkan bahwa terdapat beberapa faktor yang menyebabkan pemertahanan penggunaan bahasa Indonesia oleh subjek penelitian ini, yaitu:

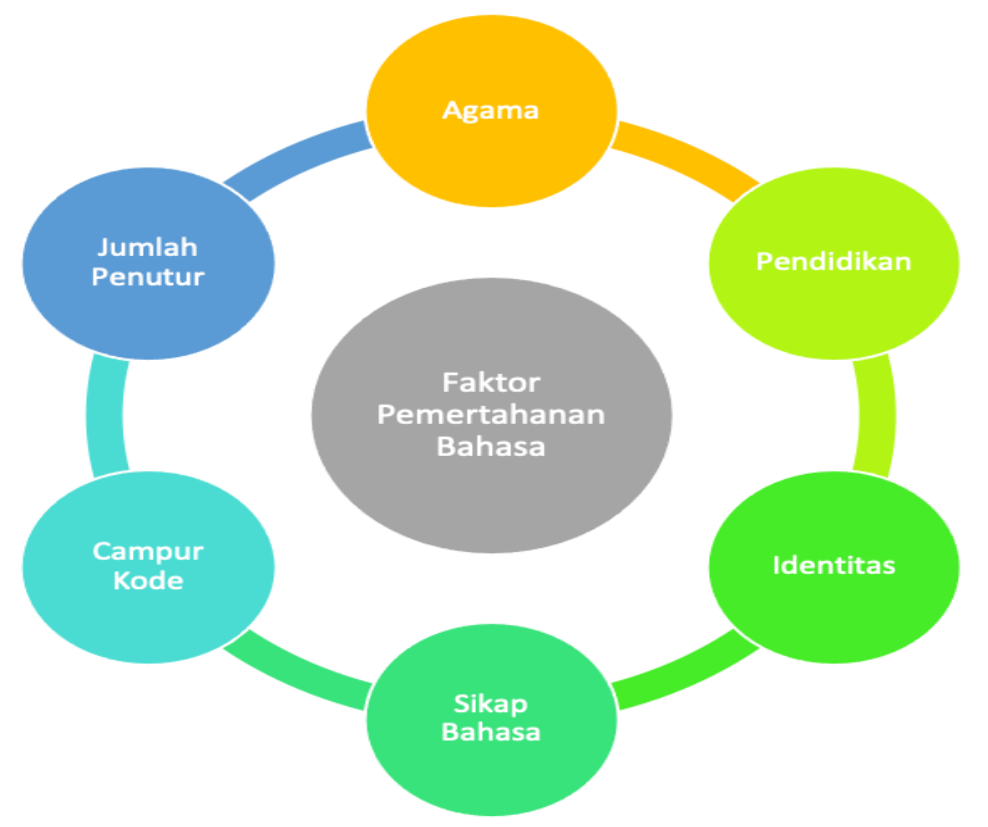

Gambar 3.

Faktor Pemertahanan Bahasa oleh Subjek Penelitian

a. Agama

Menurut hasil penelitian yang diperoleh, peneliti menemukan bahwa agama merupakan salah satu faktor mengapa subjek penelitian ini menggunakan bahasa Indonesia. Seperti yang kita ketahui, daerah kabupaten Karo merupakan daerah yang mayoritas penduduknya adalah non muslim, jadi mereka yang berbahasa daerah, bahasa Karo, sebagian besar adalah non muslim. Subjek penelitian ini adalah seorang muslim.untuk menunjukkan identitasnya sebagai seorang muslim, subjek penelitian menggunakan bahasa Indonesia sebagai bahasa dalam berkomunkasi dengan 
lingkungannya.

b. Pendidikan

Berdasarkan hasil angket, observasi, dan wawancara yang dilakukan peneliti pada subjek penelitian, peneliti menemukan bahwa pendidikan merupakan salah satu faktor penyebab subjek penelitian menggunakan bahasa Indonesia. Menurut subjek penelitian ini, penggunaan bahasa Indonesia dalam komunikasi sehari-hari menunjukkan tingkat pendidikan seseorang. Dengan kata lain, jika seseorang itu memiliki pendiidkan yang tinggi, secara otomatis ia akan menggunakan bahasa Indonesia dalam berkomunikasi dengan lingkungannya.

c. Jumlah penutur (lingkungan)

Jumlah penutur juga merupakan salah satu faktor penyebab subjek penelitian menggunakan bahasa Indonesia. Menurut hasil wawancara dan observasi, keluarga dan juga tetangga di sekitar tempat tinggal subjek penelitian ini terdiri dari banyak suku berbeda, seperti Mandailing, Jawa, maupun suku Minang. Selain karena keluarga subjek adalah orang Sunda dan menggunakan bahasa Indonesia dalam komunikasi mereka sehari-hari di rumah, tetangga sekitar mereka juga menggunakan bahasa Indonesia dalam berkomunikasi, begitupun juga dengan suku Karo yang tinggal di lingkungan mereka. Suku Karo yang tinggal di lingkungan tersebut juga menggunakan bahasa Indonesia dalam berkomunikasi. Jadi jumlah penutur bahasa Indonesia di lingkungan tersebut merupakan salah satu faktor mengapa subjek penelitian ini mempertahankan bahasa Indonesia sebagai bahasa untuk berkomunikasi sehari-hari.

d. Identitas

Seperti yang sudah dijelaskan sebelumnya, subjek penelitian ini merupakan suku Sunda yang tinggal di wilayah kabupaten Karo. Untuk menunjukkan identitasnya sebagai suku Sunda, subjek penelitian menggunakan bahasa Indonesia sebagai bahasa sehari-hari dikarenakan subjek hanya paham sedikit mengenai bahasa Sunda. Dengan kata lain, pemertahanan bahasa Indonesia oleh subjek untuk menunjukkan bahwa dia bukan suku Karo.

e. Sikap Bahasa

Berdasarkan hasil angket yang telah diisi oleh subjek penelitian, ditemukan bahwa subjek penelitian ini menunjukkan sikap bahasa yang positif terhadap bahasa Indonesia. Bahasa Indonesia dianggap sebagai bahasa yang menunjukkan tingkat 
pendidikan seseorang, kepercayaan diri, lambang kesetiaan, keakraban, dan bukti bahwa seseorang itu modern jika ia menggunakan bahasa Indonesia daripada menggunakan bahasa daerah.

\section{f. Campur Kode}

Campur kode juga merupakan salah satu faktor penyebab subjek penelitian mempertahankan bahasa Indonesia sebagai bahasa untuk berkomunikasi sehari-hari. Ini dikarenakan subjek penelitian merasa tidak nyaman untuk berbahasa Karo, disebabkan karena logat yang tidak sesuai dan pandangan bahwa penggunaan bahasa Indonesia memiliki prestige yang lebih tinggi dibandingkan penggunaan bahasa daerah. Selain itu, faktor keluarga dan lingkungan yang juga berbahasa Indonesia juga menyebabkan subjek menggunakan campur kode, bahasa Indonesia dan Karo.

\section{KESIMPULAN}

Berdasarkan kesimpulan dari beberapa pakar mengenai pemertahanan Bahasa, terdapat beberapa faktor yang mempengaruhi seseorang mempertahankan Bahasa, diantaranya: ekonomi, agama, politik, identitas dan kebanggan budaya, ranah partisipan, migrasi, jumlah penutur, tempat tinggal, latar belakang pendidikan, menghubungi famili di kampung halaman, sikap bahasa, perkawinan tidak sesuku, administrasi, pekerjaan, umur, jenis kelamin, alih kode, campur kode. Namun hanya ada beberapa dari faktor di atas yang mempengaruhi subjek penelitian ini melakukan pemertahanan Bahasa Indonesia di tengah Bahasa Karo di desa Tiga Panah kabupaten Karo, yaitu agama, pendidikan, identitas, sikap bahasa, campur kode, dan jumlah penutur.

Hal ini menunjukkan bahwa Bahasa Indonesia memegang peranan penting bagi subjek penelitian ini karena Bahasa Indonesia menunjukkan bahwa Pendidikan seseorang itu tinggi, dengan kata lain penggunaan bahsaa Indonesia lebih memiliki prestige yang lebih tinggi daripada penggunaan Bahasa daerah. Selain itu, Bahasa Indonesia juga merupakan Bahasa universal karena ada beberapa Bahasa daerah, seperti pada penelitian ini, Bahasa daerah Karo. Pengguna Bahasa Karo biasanya dianggap sebagai bahasas non muslim karena mayoritas penduduk kabupaten Karo adalah non muslim, jadi untuk menunjukkan agama dan identitas sukunya, subjek penelitian ini mempertahankan Bahasa Indonesia ditengah Bahasa Karo di desa Tiga Panah kabupaten Karo. Jumlah penutur Bahasa juga turut mempengaruhi mengapa seseorang mempertahankan bahasanya, seperti yang ditemukan pada penelitian ini, 
jumlah penutur Bahasa Indonesia di lingkungan subjek penelitian termasuk banyak daripada penutur Bahasa Karo itu sendiri dikarenakan di lingkungan tempat tinggal subjek sudah banyak pendatang diluar suku Karo.

Berdasarkan hasil penelitian diatas, peneliti menyarankan bagi peneliti selanjutnya yang juga tertarik di bidang linguistuk, khususnya pemertahanan Bahasa untuk menggali lebih dalam lagi mengenai penggunaan Bahasa pada seseorang atau suku di daerah yang punya Bahasanya tersendiri dan hasil penelitian ini diharapkan bias menjadi salah satu referensi bagi peneliti selanjutnya yang tertarik dalam penelitian bidang linguitik khususnya pemertahanan Bahasa.

\section{DAFTAR PUSTAKA}

Abdul Chaer dan Leonie Agustina. 2004. Sosiolinguistik. Jakarta: Rineka Cipta.

Aslinda dan Leni Syafyahya. 2010. Pengantar Sosiolinguistik. Bandung: Refika Aditama.

Botifar, Maria. 2018. Pemertahanan Bahasa dan Pengembangan Kurikulum Bahasa Berbasis Analisis Kebutuhan. Sumber: repository.unib.ac.id/11127/1/22-Maria\%20Botifar.pdf

Bramono, Nurdin \& Rahman, Mifta. 2012. Pergeseran dan Pemertahanan Bahasa.

Sumber: journal.unipdu.ac.id:8080/index.php/diglosia/article/view/226

Jendra, Iwan Indrawan. 2010. Sociolinguistics: The Study of Societies' Language. Yogyakarta: Graha IImu

Miles, M.B., M.A Huberman., \& J. Saldana. 2014. Qualitative Data Analysis: A Methods Sourcebook. USA: Sage.

Romaine. 2000. Language in Society: An Introduction to Sociolinguistics. New York: Oxford University Press.

Suharsimi Arikunto. 2002. Prosedur Penelitian Suatu Pendekatan Praktek. Jakarta: Rineka Cipta.

Sumarsono. 2004. Sosiolinguistik. Yogyakarta: Sabda.

Wibowo, Wahyu. 2001. Otonomi Bahasa 7 Strategi Tulis Pragmatik bagi Praktisi Bisnis dan Mahasiswa, Jakarta: Gramedia Pustaka Utama.

Widianto, Eko. 2016. "Pilihan Bahasa dalam Interaksi Pembelajaran Bahasa Indonesia bagi Penutur Asing”. Seloka: Jurnal Pendidikan Bahasa dan Sastra Indonesia. Volume 5 nomor 2. Hal. 124-135.

Widianto, Eko. 2018. Pemertahanan Bahasa Daerah melalui Pembelajaran dan Kegiatan di Sekolah. Sumber: https://jurnal.umk.ac.id/index.php/kredo/article/view/2096 